\title{
Front Matter: Volume 11241
}

, "Front Matter: Volume 11241," Proc. SPIE 11241, Biophotonics and Immune Responses XV, 1124101 (4 March 2020); doi: 10.1117/12.2566011

SPIE. Event: SPIE BiOS, 2020, San Francisco, California, United States 


\section{PROGRESS IN BIOMEDICAL OPTICS AND IMAGING}

\section{Biophotonics and Immune Responses XV}

Wei R. Chen

Editor

3 February 2020

San Francisco, California, United States

Sponsored and Published by

SPIE 
The papers in this volume were part of the technical conference cited on the cover and title page. Papers were selected and subject to review by the editors and conference program committee. Some conference presentations may not be available for publication. Additional papers and presentation recordings may be available online in the SPIE Digital Library at SPIEDigitalLibrary.org.

The papers reflect the work and thoughts of the authors and are published herein as submitted. The publisher is not responsible for the validity of the information or for any outcomes resulting from reliance thereon.

Please use the following format to cite material from these proceedings:

Author(s), "Title of Paper," in Biophotonics and Immune Responses XV, edited by Wei R. Chen, Proceedings of SPIE Vol. 11241 (SPIE, Bellingham, WA, 2020) Seven-digit Article CID Number.

ISSN: 1605-7422

ISSN: $2410-9045$ (electronic)

ISBN: 9781510632455

ISBN: 9781510632462 (electronic)

Published by

SPIE

P.O. Box 10, Bellingham, Washington 98227-0010 USA

Telephone +1 3606763290 (Pacific Time) · Fax +1 3606471445

SPIE.org

Copyright (c) 2020, Society of Photo-Optical Instrumentation Engineers.

Copying of material in this book for internal or personal use, or for the internal or personal use of specific clients, beyond the fair use provisions granted by the U.S. Copyright Law is authorized by SPIE subject to payment of copying fees. The Transactional Reporting Service base fee for this volume is $\$ 21.00$ per article (or portion thereof), which should be paid directly to the Copyright Clearance Center (CCC), 222 Rosewood Drive, Danvers, MA 01923. Payment may also be made electronically through CCC Online at copyright.com. Other copying for republication, resale, advertising or promotion, or any form of systematic or multiple reproduction of any material in this book is prohibited except with permission in writing from the publisher. The CCC fee code is $1605-$ $7422 / 20 / \$ 21.00$.

Printed in the United States of America by Curran Associates, Inc., under license from SPIE.

Publication of record for individual papers is online in the SPIE Digital Library.

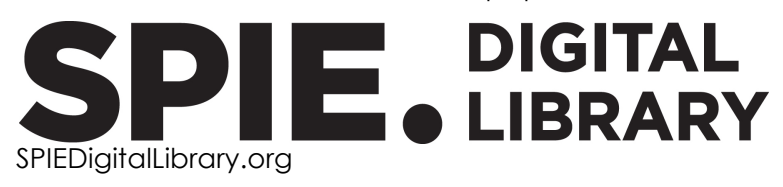

Paper Numbering: Proceedings of SPIE follow an e-First publication model. A unique citation identifier (CID) number is assigned to each article at the time of publication. Utilization of CIDs allows articles to be fully citable as soon as they are published online, and connects the same identifier to all online and print versions of the publication. SPIE uses a seven-digit CID article numbering system structured as follows:

- The first five digits correspond to the SPIE volume number.

- The last two digits indicate publication order within the volume using a Base 36 numbering system employing both numerals and letters. These two-number sets start with 00, 01, 02, 03, 04, 05, 06, 07, 08, 09, OA, OB ... 0Z, followed by 10-1Z, 20-2Z, etc. The CID Number appears on each page of the manuscript. 


\title{
Contents
}

\author{
$\checkmark \quad$ Authors \\ vii Conference Committee
}

NOVEL DETECTION TECHNOLOGIES

$11241 \mathrm{OF} \quad$ Utilizing a transfer model to classify epithelium and stroma on digital histopathological images for ovarian cancer patients (Invited Paper) [11241-14]

$11241 \mathrm{OH} \quad$ Photoacoustic microscopy for bone microstructure analysis [11241-16]

POSTER SESSION

11241 OT Label-free counting of circulating melanoma cells in deep vessels with photoacoustic flow cytometry [11241-28]

$112410 \mathrm{U}$ Virtual screened peptides with high affinity to integrin a $5 \boldsymbol{\beta} \mathbf{1}$ for precise tumor identification and treatment [11241-29]

11241 OY Developing a low cost image marker to identify lymph node metastasis for cervical cancer patients: an initial study [11241-33]

1124114 The feasibility of utilizing the mid-energy in-line phase-contrast imaging system in the breast x-ray imaging [1 1241-39] 
Proc. of SPIE Vol. 11241 1124101-4

\section{Downloaded From: https://www.spiedigitallibrary.org/conference-proceedings-of-spie on 26 Apr 2023
Terms of Use: https://www.spiedigitallibrary.org/terms-of-use}




\section{Authors}

Numbers in the index correspond to the last two digits of the seven-digit citation identifier (CID) article numbering system used in Proceedings of SPIE. The first five digits reflect the volume number. Base 36 numbering is employed for the last two digits and indicates the order of articles within the volume. Numbers start with 00, 01, 02, 03, 04, 05, 06, 07, 08, 09, 0A, 0B...0Z, followed by 10-1Z, 20-2Z, etc.

Arellano, Jesus, $\mathrm{OH}$

Castellano, Tara, OY

Chen, Xuxin, OF, OY

Fu, Yuting, OT

Fung, Kar-Ming, OF

Ghani, Muhammad U., 14

Gong, Shuaishuai, OU

Gu, Yueqing, OU

Gunderson, Camille C., OY

Han, Zhihao, OU

Li, Yuhua, 14

Liu, Hong, OF, OY, 14

Liv, Qi, OT

Liu, Wei, OY

Mannel, Robert S., OY

Merrill, John A., $\mathrm{OH}$

Moore, Kathleen, OY

Omoumi, Farid H., 14

Pei, Shiyu, OY

Qian, Zhiyu, OU

Qiu, Yuchen, OF, OY, 14

Tao, Lechan, OT

Thai, Theresa C., OY

Wang, Siqi, $\mathrm{OH}$

Wei, Xunbin, OT

Wong, Molly D., 14

Xiang, Liangzhong, $\mathrm{OH}$

Zhang, Roy, OF

Zhao, Yue, $\mathrm{OH}$

Zheng, Bin, OF, OY

Zhou, Quanyu, OT

Zhu, Xi, OT 
Proc. of SPIE Vol. 11241 1124101-6

Downloaded From: https://www.spiedigitallibrary.org/conference-proceedings-of-spie on 26 Apr 2023 Terms of Use: https://www.spiedigitallibrary.org/terms-of-use 


\section{Conference Committee}

Symposium Chairs

Jennifer K. Barton, The University of Arizona (United States)

Wolfgang Drexler, Medizinische Universität Wien (Austria)

Program Track Chairs

E. Duco Jansen, Vanderbilt University (United States)

Jessica C. Ramella-Roman, Florida International University

(United States)

Conference Chair

Wei R. Chen, University of Central Oklahoma (United States)

Conference Program Committee

Sandra O. Gollnick, Roswell Park Comprehensive Cancer Center (United States)

Michael R. Hamblin, Wellman Center for Photomedicine (United States)

Tomas Hode, Immunophotonics, Inc. (United States)

Yih-Chih Hsu, Chung Yuan Christian University (Taiwan)

Mladen Korbelik, BC Cancer Research Center (Canada)

Hong Liu, The University of Oklahoma (United States)

Mark F. Naylor, Dermatology Associates of San Antonio (United States)

Junle Qu, Shenzhen University (China)

Oxana V. Semyachkina-Glushkovskaya, Saratov State University (Russian Federation)

Robert T. van Kooten, Amsterdam UMC (Netherlands)

Xunbin Wei, Shanghai Jiao Tong University (China)

Da Xing, South China Normal University (China)

Zhihong Zhang, Huazhong University of Science and Technology (China)

Feifan Zhou, Shenzhen University (United States)

Session Chairs

1 Phototherapy and Immunotherapy

Mark F. Naylor, Baylor Scott \& White Health (United States)

Oxana V. Semyachkina-Glushkovskaya, Saratov State University (Russian Federation) 
2 Nanotechnology-Based Photo-Immunotherapy

Feifan Zhou, Shenzhen University (China)

Wei R. Chen, University of Central Oklahoma (United States)

3 Monitoring Immune Responses

Zhihong Zhang, Huazhong University of Science and Technology (China)

Ekaterina I. Galanzha, University of Arkansas for Medical Sciences (United States)

4 Novel Detection Technologies

Yuchen Qiu, The University of Oklahoma (United States)

Dmitry A. Gorin, Skolkovo Institute of Science and Technology (Russian Federation) 